\title{
Hemşirelik Öğrencilerinin Çocuk İstismarı ve İhmalinin Belirti ve Risklerini Tanılama Düzeyleri
}

\author{
DOI: 10.26466/opus.511405 \\ * \\ Emine Güdek Seferoğlu*- $\underline{\text { Emel Sezici }}^{* *}$ - Deniz Yiğit ${ }^{* * *}$ \\ * Dr. Öğr. Üyesi Kütahya Sağlık Bilimleri Üniversitesi, Sağlık Bilimleri Fak., Kütahya / Türkiye \\ E-Posta: emine.gudekseferoglu@ksbu.edu.tr ORCID: 0000-0001-5803-0059 \\ ** Dr. Öğr. Üyesi Kütahya Sağlık Bilimleri Üniversitesi, Sağlık Bilimleri Fak., Kütahya / Türkiye \\ E-Posta: emel.sezici@ksbu.edu.tr \\ ORCID: 0000-0002-6325-6607 \\ *** Arş. Grv. Eskişehir Osmangazi Üniversitesi, Sağlık Bilimleri Fakültesi, Eskişehir / Türkiye \\ E-Posta: deniz.yigit@dpu.edu.tr \\ ORCID: $\underline{0000-0001-5627-7963}$
}

Öz

Bu araştırma, hemşirelik öğrencilerinin çocuk istismarı ve ihmalinin belirti ve risklerini tanıyabilme düzeylerini belirlemeyi amaçlamıştır. Tanımlayıcı tipte araştırmanın evrenini 2017-2018 öğretim yılı bahar yarıyılında bir üniversitenin hemşirelik bölümüne kayıtl 2. ve 4. sinıf öğrencileri, örneklemini ise çalışma kriterlerine uyan 217 öğrenci (\%92) oluşturdu. Verilerin toplanmasında "Tanıtıcı Bilgi Formu" ve "Çocuk İstismarı ve İhmalinin Belirti ve Risklerinin Tanılanması Ölçeği" kullanıldı. İstatistiksel analizler SPSS 20.0 paket programında tanımlayıcı istatistiksel yöntemler (frekans ve yüzdelikler), bağımsız gruplarda t testi ve tek yönlü varyans analizi ile yapıldı. Öğrencilerin çocuk istismar ve ihmalinin belirti ve risklerinin tanılanması toplam ölçek puanlarının genel ortalaması 243,65 23,05 olarak saptanmıştır. Araştırmada 4. sınıf, kadın, çocuk istismarı ve ihmali ile ilgili eğitimi okul aracılı̆̆ ile almış olan öğrencilerin çocuk istismarı ve ihmalinin belirti ve risklerinin tanılanması ölçek puan ortalamalarının daha yüksek olduğu bulunmuştur $(p<0,05)$. Hemşirelik öğrencilerinin çocuk istismarı ve ihmalinin belirti ve risklerini tanıyabilme düzeylerinin istendik düzeyde olmadığı, çocuk ihmali ve istismarı konusunda yasal sorumlulukların bilmedikleri ve eğitime gereksinim duydukları belirlenmiştir.

Anahtar Kelimeler: Çocuk istismarı ve ihmali, Hemşirelik, Üniversite öğrencileri 


\title{
Nursing Students' Level of the Diagnosing Symptoms and Risks of Child Abuse and Neglect
}

\begin{abstract}
This research has aimed to determine the competency level of the nursing students, in recognizing the signs and risks of child abuse and neglect. This descriptive study has been conducted on the students who have been studying in the 2 nd and 4 th year of nursing faculty of a university, during the spring semester in 2017-2018 Academic Year. The samples cover 217 students (92\%) who met the study criteria. The data were obtained by using "The Identification Information Form" and "Scale of Diagnosing Symptoms and Risks of Child Abuse and Neglect". The statistical analysis of the data was performed using 20.0 SPSS package program, applying the frequency, percentages, the Student's $t$-test and oneway analysis of variance methods. The overall average scores of the students for the Diagnosing Symptoms and Risks of Child Abuse and Neglect Scale were 243,65 23,05. In this study, the students who are 4th graders, female, have been trained on child abuse and neglect subject and have received this education through schools were found to be have higher scale of the diagnosing symptoms and risks of child abuse and neglect $(p<0,05)$. It has been determined that the nursing students' ability to recognize the symptoms and risks of child abuse and neglect is not at an expected level, they are not aware of their legal responsibilities about child abuse and neglect and need education.
\end{abstract}

Keywords: Child abuse and neglect, Nursing, University students 


\section{Giriş}

Dünya Sağlık Örgütü (DSÖ) çocuk ihmalini ve istismarını "18 yaşın altındaki çocukların sağlığını, büyüme ve gelişmesini, ilişkilerdeki güven duygusunu olumsuz yönde etkileyen fiziksel, duygusal, cinsel yönden istismar ve ihmal türleriyle sonuçlanan kötü davranışlar" olarak tanımlamaktadır (WHO, 2018). İhmal ve istismar çocukların, fiziksel, zihinsel veya sosyal yönden gelişimini etkileyerek erişkin dönemlerine kadar uzanan birçok problem yaşamasına neden olmaktadır (Bakır ve Kapucu, 2017; Karakuş, 2012; Özgentürk, 2014). Bu nedenle, gelecek nesillerin sağlam temeller üzerinde kurulabilmesi için çocukların fiziksel ve ruhsal sağlıklarının korunması oldukça önemlidir (Caneira ve Myrick, 2015; Kürklü, 2011).

Çocuk ihmalinin ve istismarının (Çi̇̈) önlenmesi, erken tanılanması ve gerekli prosedürlerin uygulanmasında sağlık çalışanlarına (Ceccucci, 2018; Geçkil, 2017) ve bu grubun önemli bir çoğunluğunu oluşturan hemşirelere önemli görevler düşmektedir (Güner, Yavuz ve Dörtbudak, 2016; Sekhar ve ark., 2018). DSÖ de Çiİ'nin önlenmesinde hemşirelerin çocuk gelişim dönemlerini iyi bilmek, büyüme ve gelişmede normalden sapmaları tespit etmek, anormal durumlarda prosedürleri bilmek, ailelere ve kişilere gerekli eğitimleri vermek gibi önemli sorumlulukları olduğunu vurgulamaktadır (WHO, 2018).

Ülkemizde Çi̇̇ olaylarının tespit edilmesi ya da kayıt altına alınmasinda ciddi yetersizlikler vardır. Bunun nedenlerinden biri de bu olgularla en sık karşılaşan sağlık personelinin bu olgulardaki bulguları tespit etmedeki yetersizlikleridir (Bakır ve Kapucu, 2017; Külcü Polat ve Karalaş, 2016). Yapılan bir çalışmada hemşirelerin \%54,3'ünün Çi̇̇ olgusuyla karşılaştığında izlemesi gereken prosedür konusunda yetersiz olduğu belirtilmiştir (Gölge, Hamzaoglu ve Türk, 2012). Başka bir çalışmada sağlık çalışanlarının \%59,1'i lisans öğrenimi sırasında, \%98,2'si ise mezuniyet sonrasında çiì konusunda herhangi bir eğitim almadıkları belirlenmiştir (Metinyurt ve Sarı, 2016). Diğer çalışmalarda da hemşirelerin Çi̇̇ konusunda eğitime ihtiyaçları olduğu (Türker, 2017; Ben ve ark., 2010), eğitim alan hemşirelerin çocuk istismarı ve ihmalinin belirti ve risklerini tanılama (Çi்IBRT) düzeylerinin daha yüksek olduğu bildirilmiştir (Burç ve Güdücü Tüfekçi, 2015). Türkiye'de yapılan bir çalışmada da bu alanda yapılan ça- 
lışmaların sadece \%11,83'ünün hemşireler ile yapıldığı belirtilmiştir (Bakır ve Kapucu, 2017). Hemşirelik öğrencilerinin daha donanımlı yetişebilmesi için çocuk istismarı ve ihmalinin belirti ve risklerinin hemşirelik eğitim müfredatlarına eklenmesi, tanılama, bildirim yapma sürecine ayrıntılı yer verilmesi, çalışan hemşireler için hizmet içi eğitim programlarının düzenlenmesi ve bu alanda yapılan çalışmalarda hemşirelerin aktif olarak yer alması oldukça önemlidir (Engh Kraft, Rahm ve Eriksson, 2017; Lee ve Kim, 2018). Bu bağlamda, çalışma, geleceğin sağlık personeli hemşirelik öğrencilerinin çocuk istismarı ve ihmalinin belirti ve risklerini tanıyabilme düzeylerini belirlemek amacıyla yapılmıştır.

\section{Araştırma Soruları}

1. Öğrencilerin sosyo-demografik değişkenler ve Çi̇i ile ilgili sahip oldukları özelliklere göre Çï̈BRTÖ'den aldıkları puan ortalamaları arasında ilişki var mıdır?

2. Öğrencilerin sınıflarına göre Çİ̈BRTÖ'den aldıkları puan ortalamaları arasında ilişki var mıdır?

\section{Yöntem}

\section{Çalışmanın Tipi, Zamanı ve Yeri}

Kesitsel tipte tanımlayıcı olan bu çalışma Nisan-Mayıs 2018 tarihleri arasinda hemşirelik bölümü öğrencilerinde gerçekleştirildi.

\section{Çalışmanın Evren ve Örneklemi}

Çalışmaya dahil edilme kriterlerimiz; öğrencinin 2. veya 4. sınıf hemşirelik bölümü öğrencisi olması, öğrencinin çalışmaya katılmayı kabul etmesidir. Çalışmanın evrenini 2017-2018 Eğitim ve Öğretim Dönemi Bahar yarıyılında hemşirelik bölümüne kayıtlı 235 öğrenci (2. ve 4. sınıf) oluşturdu. Öğrencilerden 18 tanesi uygulamayı kabul etmedi. Çalışma örneklemine ise çalışma kriterlere uyan 217 öğrenci (\%92) dahil edildi. 


\section{Veri Toplama Araçları}

Çalışma verileri, “Tanıtıcı Bilgi Formu” ve "Çocuk İstismarı ve İhmalinin Belirti ve Risklerinin Tanılanması Ölçeği (Çİ̈BRTÖ)" ile toplanmıştır. Araştırmacılar tarafından oluşturulan "Tanıtıcı Bilgi Formu" yaş, cinsiyet, medeni durum, aile tipi gibi bilgileri sorgulayan 17 sorudan oluşmaktadır. 1998 yılında Uysal tarafından geliştirilen ölçek ise hemşirelerin bilgi düzeylerini ölçmeye yönelik toplam 67 sorudan oluşmaktadır. Ölçek, istismarın çocuk üzerindeki fiziksel belirtileri (19 madde), çocuk istismarına ilişkin çocuktaki davranışsal belirtileri (15 madde), ihmalin çocuk üzerindeki belirtileri (7 madde), ihmal ve istismara yatkın ebeveyn özellikleri (13 madde), ihmal ve istismara yatkın çocukların özellikleri (5 madde), çocuk ihmal ve istismarında ailesel özellikleri ( 8 madde) olmak üzere 6 alt gruptan oluşan 5'li likert tipi bir ölçektir. Ölçeğin Cronbach alfa değeri 0,92 bulunmuştur (Uysal, 1998). Bu çalışmada ise ölçeğin Cronbach alfa değeri 0.88 bulunmuştur.

\section{Verilerin Toplanmas1}

Veriler, öğretim elemanları gözetiminde ders saati dışında öğrenciler tarafından doldurularak elde edildi. Çalışmanın amacı ve süresi açıklandıktan sonra öğrenciler "Tanıtıcı Bilgi Formu" ve "Çocuk İstismarı ve İhmalinin Belirti ve Risklerinin Tanılanması Ölçeği" ni doldurdu. Veri formlarının doldurulması yaklaşık 30 dakikalık bir süre içinde tamamlandı.

\section{Etik Konular}

Çalışmanın uygulanabilmesi için etik kurul onayı (2018/20 sayılı) ve üniversite rektörlüğünden kurum izni alındı. Öğrencilere çalışmanın amacı hakkında bilgi ve verilerin kimseyle paylaşılmayacağına ilişkin güvence verilerek öğrencilerden bilgilendirilmiş gönüllü olur alındı.

\section{Verilerin Analizi}

İstatistiksel analizler SPSS 20.0 paket program kullanılarak yapılmıştır. İs- 
tatiksel değerlendirmede ölçek ve alt ölçek toplam puanlarının normal dağılıma uygunluğu Shapiro-Wilk testi ile belirlenmiş ve verilerin normal dağılım gösterdiği saptanmıştır. Tanımlayıcı istatistik analizinde sayı, yüzde, ortalama, standart sapma; gruplara göre değişkenlerin karşılaştırılmasında ki-kare; değişkenlerin gruplara göre karşılaştırılmasında 2 gruplu olanlar için bağımsız gruplarda t testi, 3 ve daha fazla değişkenli olanlarda tek yönlü varyans analizi (ANOVA) kullanılmıştır. İstatistiksel testlerde $\mathrm{p}<0,05$ değeri istatistiksel olarak anlamlı kabul edilmiştir.

\section{Çalışmanın Sınırlılıkları}

Çalışma tek bir kurumda yürütülmüş olup, sonuçlar yalnızca çalışmanın yürütüldüğü okuldaki öğrencileri kapsar. Bu nedenle bu çalışma sonuçları diğer bütün kurumlardaki öğrencilere genellenemez olması çalışmanın ilk sınırlılığıdır. Ayrıca çalışma verilerinin sadece öğrencilerden elde edilmesi ve gözleme dayalı bulgular içermemesi de çalışmanın bir diğer sinırlılı̆̆ıdır.

\section{Bulgular}

Tablo 1'de çalışmaya katılan öğrencilerin tanıtıcı özellikleri incelendiğinde öğrencilerin \%71'inin kadın, \%29'unun erkek, \%98,2'sinin bekar, \%20,7'sinin sağlik meslek lisesinden mezun olduğu saptanmıştır. Öğrencilerin \%76,5'inin ekonomik durumunun gelir gidere denk, \%84,3'ünün çekirdek aile yapısında, \%71,9'unun annesinin ve \%41,5'inin babasının ilkokul mezunu olduğu belirlenmiştir. Çalışmaya katılanların \%59'u 1-2 kardeşe sahip olup, \%75,6'sı şehirde yaşamaktadır. Öğrencilerin çocuk sahibi olma durumlarına bakıldığında sadece dört öğrencinin çocuk sahibi olduğu saptanmıştır. Çocuk istismar ve ihmali konusunda öğrencilerin eğitim alma durumları incelendiğinde, \%67,7'si bilgi aldıklarını; \%38,7'si bu bilgiyi televizyon, dergi, kitap ya da gazeteden, $\% 19,8$ 'si okuldan, $\% 9,2$ 'si de seminer ya da konferans ile edindiklerini belirtmişlerdir. Öğrencilerin \%32,3'ü ise hiçbir yerden eğitim almadıklarını bildirmişlerdir. 
Tablo 1. Öğrencilerin tanıtıcı özellikleri ile Çİ̈BRTÖ toplam puanının karşılaştırılması

\begin{tabular}{|c|c|c|c|c|c|}
\hline Özellikler & $\mathbf{n}$ & $\%$ & $\begin{array}{l}\text { Toplam Ölçek Puanı } \\
\text { Ort } \pm \text { Ss }\end{array}$ & $t$ testi & p \\
\hline \multicolumn{6}{|l|}{ Cinsiyet } \\
\hline Kadın & 154 & 71 & $249,24 \pm 22,53$ & \multirow{2}{*}{6,013} & \multirow{2}{*}{,001 } \\
\hline Erkek & 63 & 29 & $230,01 \pm 18,22$ & & \\
\hline \multicolumn{6}{|l|}{ Anne Eğitimi } \\
\hline İlkokul ve altı & 156 & 56,1 & $242,04 \pm 22,38$ & \multirow{2}{*}{$-1,65$} & \multirow{2}{*}{,375 } \\
\hline Ortaokul ve üzeri & 122 & 43,9 & $243,71 \pm 24,29$ & & \\
\hline \multicolumn{6}{|l|}{ Baba Eğitimi } \\
\hline İlkokul ve altı & 90 & 41,5 & $240,66 \pm 23,73$ & \multirow{2}{*}{$-1,61$} & \multirow[t]{2}{*}{,365 } \\
\hline Ortaokul ve üzeri & 127 & 58,5 & $245,77 \pm 22,40$ & & \\
\hline \multicolumn{6}{|l|}{ Mezun Olunan Okul } \\
\hline SML & 45 & 20,7 & $247,47 \pm 24,22$ & \multirow{2}{*}{1,246} & \multirow{2}{*}{214} \\
\hline Diğer & 172 & 79,3 & $242,66 \pm 22,71$ & & \\
\hline \multicolumn{6}{|l|}{ Kardeş Sayısı } \\
\hline $1-2$ & 128 & 59 & $246,73 \pm 22,15$ & \multirow{3}{*}{5,517} & \multirow{3}{*}{,005 } \\
\hline $3-4$ & 62 & 28,6 & $242,85 \pm 22,45$ & & \\
\hline 5 ve üzeri & 27 & 12,4 & $230,93 \pm 24,89$ & & \\
\hline \multicolumn{6}{|l|}{ Yaşanilan Yer } \\
\hline Köy & 33 & 15,2 & $235,52 \pm 19,57$ & \multirow{3}{*}{6,181} & \multirow{3}{*}{,002 } \\
\hline Kasaba & 20 & 9,2 & $232,30 \pm 19,80$ & & \\
\hline Şehir & 164 & 75,6 & $246,68 \pm 23,34$ & & \\
\hline \multicolumn{6}{|c|}{ Çocuk Sahibi Olma Durumu } \\
\hline Evet & 4 & 1,8 & $263,75 \pm 40,29$ & \multirow{2}{*}{1,768} & \multirow{2}{*}{,078 } \\
\hline Hayır & 213 & 98,2 & $243,28 \pm 22,60$ & & \\
\hline \multicolumn{6}{|c|}{ Çî̀ ile İlgili Eğitim Alma Durumu } \\
\hline Evet & 147 & 67,7 & $247,37 \pm 23,77$ & \multirow{2}{*}{3,791} & \multirow{2}{*}{,001 } \\
\hline Hayır & 70 & 32,3 & $235,86 \pm 19,42$ & & \\
\hline Eğitimin Alındığı Yer & & & & & \\
\hline Okul & 43 & 19,8 & $250,26 \pm 23,73$ & & \\
\hline Seminer/Konferans & 20 & 9,2 & $241,50 \pm 27,25$ & & \\
\hline Tv/Dergi/Kitap/Gazete & 84 & 38,7 & $247,30 \pm 22,94$ & 4,848 & ,003 \\
\hline Hiçbir yerden & 70 & 32,3 & $235,86 \pm 19,42$ & & \\
\hline Çî̉ Olgusu ile Karşılaş & Irumu & & & & \\
\hline Evet & 43 & 19,8 & $246,16 \pm 25,49$ & & \\
\hline Hayır & 174 & 80,2 & $243,04 \pm 22,45$ & 0,795 & 428 \\
\hline Çi̇ Tanımada Yeterli C & & & & & \\
\hline Evet & 95 & 43,8 & $244,38 \pm 23,71$ & & \\
\hline Hayır & 122 & 56,2 & $243,10 \pm 22,61$ & 0,405 & 686 \\
\hline Çi̇i ile İlgili Yasal Soru & kları I & & & & \\
\hline Evet & 53 & 24,4 & $248,60 \pm 25,39$ & 1806 & \\
\hline Hayır & 164 & 75,6 & $242,06 \pm 22,09$ & 1,806 & , \\
\hline Çi̇i ile İlgili Eğitim Aln & teme & & & & \\
\hline Evet & 178 & 82 & $245,19 \pm 23,26$ & & \\
\hline Hayır & 39 & 18 & $236,67 \pm 20,95$ & 2,108 & ,036 \\
\hline
\end{tabular}


Çalışmaya katılan öğrencilerin \%80,2'si istismar ya da ihmal olgusu ile karşılaşmadığını, \%43,8'i olguyla karşılaşma durumunda kendini yeterli gördügüüü, \%59,9'u istismar ya da ihmal ile gelen çocuğa yaklaşımı bilmediğini, \%75,6'sının ise çocuk istismar ve ihmali ile ilgili yasal sorumluluklarını bilmediğini ve \%82'sinin bu konu hakkında eğitim almak istediği belirlenmiştir.

Tablo 1'de görüldüğü gibi cinsiyet, kardeş sayısı, yaşanılan yer, eğitim alma durumu, eğitimin alındığı yer ve eğitim almak isteme ile "Çocuk İstismarı ve İhmalinin Tanılanması Ölçeği" puan ortalamaları arasında istatistiksel olarak anlamlı bir fark saptanmıştır $(\mathrm{p}<0,05)$. Kadınların puan ortalamasi $(249,24 \pm 22,53)$, erkeklerden $(230,01 \pm 18,22)$; 1 -2 kardeşi olanların puan ortalaması $(246,73 \pm 22,15), 3-4(242,85 \pm 22,45)$ ve 5 ve üzeri olanlardan (230,93 $\pm 24,89)$; şehirde yaşayanların puan ortalaması $(246,68 \pm 23,34)$, köyde $(235,52 \pm 19,57)$ ve kasabada yaşayanlardan $(232,30 \pm 19,80)$; çocuk istismarı ve ihmali konusunda eğitim alanların puan ortalaması $(247,37 \pm 23,77)$, almayanlardan $(235,86 \pm 19,42)$; okulda eğitim alanlarin puan ortalamasi $(250,26 \pm 23,73)$, seminer/konferanstan $(241,50 \pm 27,25)$ ve televizyon / dergi / kitap / gazeteden $(247,30 \pm 22,94)$; çocuk istismarı ve ihmali konusunda eğitim almak isteyenlerin puan ortalaması $(245,19 \pm 23,26)$, eğitim almak istemeyenlerden $(236,67 \pm 20,95)$ daha yüksek bulunmuştur.

Tablo 2' de 2.sınıfta olan öğrencilerin "İstismarın çocuk üzerindeki fiziksel belirtilerini tanıma" ( $p=0,001)$, "Çocuk istismarına ilişkin çocuktaki davranışsal belirtileri bilme" ( $\mathrm{p}=0,001)$, “İhmalin çocuk üzerindeki belirtilerini tanıma" ( $\mathrm{p}=0,001)$, “İstismar ve ihmale yatkın ebeveyn özelliklerini tanıma" ( $\mathrm{p}=0,001)$, “Çocuk istismarı ve ihmalinde ailesel özellikleri bilme" $(p=0,001)$ alt ölçekleri puan ortalamaları ve toplam ölçek puan ortalamaları $(\mathrm{p}=0,001)$ cinsiyete göre istatistiksel açıdan anlamlı farklılık göstermektedir. 4.sınıfta olan öğrencilerin ise "İstismarın çocuk üzerindeki fiziksel belirtilerini tanıma" ( $p=0,006)$, "Çocuk istismarına ilişkin çocuktaki davranışsal belirtileri bilme" $(p=0,011)$, "İstismar ve ihmale yatkın ebeveyn özelliklerini tanıma" ( $\mathrm{p}=0,034)$, “İstismar ve ihmale yatkın çocuğun özelliklerini bilme" $(\mathrm{p}=0,008)$ alt ölçekleri puan ortalamaları ve toplam ölçek puan ortalamaları $(\mathrm{p}=0,001)$ cinsiyete göre istatistiksel açıdan anlamlı farklılık göstermektedir. 2. ve 4 . sınıfta olan tüm kadınların ölçek ve alt 
ölçek puan ortalamaları erkeklerin puan ortalamalarından daha yüksek olduğu belirlenmiştir.

Tablo 2. Sınıfa ve cinsiyete göre ölçek alt ölçek puan ortalamalarının karşılaştırılması

\begin{tabular}{|c|c|c|c|c|c|c|}
\hline Alt Ölçekler & Sinif & Cinsiyet & $\mathbf{N}$ & $\bar{X} \pm s s$ & $\mathbf{t}$ & $\mathrm{p}$ \\
\hline \multirow{4}{*}{$\begin{array}{l}\text { İstismarın çocuk üze- } \\
\text { rindeki fiziksel belirti- } \\
\text { lerini tanıma }\end{array}$} & \multirow{2}{*}{ 2. sinif } & Kadın & 71 & $73,80 \pm 7,30$ & \multirow{2}{*}{4,418} & \multirow{2}{*}{001} \\
\hline & & Erkek & 43 & $67,67 \pm 6,97$ & & \\
\hline & \multirow{2}{*}{ 4. sinif } & Kadın & 83 & $74,01 \pm 7,70$ & \multirow{2}{*}{2,828} & \multirow{2}{*}{,006 } \\
\hline & & Erkek & 20 & $68,80 \pm 5,95$ & & \\
\hline \multirow{4}{*}{$\begin{array}{l}\text { Çocuk istismarına iliş- } \\
\text { kin çocuktaki davra- } \\
\text { nışsal belirtileri bilme }\end{array}$} & \multirow{2}{*}{ 2. sinif } & Kadın & 71 & $56,15 \pm 5,44$ & \multirow{2}{*}{3,559} & \multirow{2}{*}{,001 } \\
\hline & & Erkek & 43 & $52,37 \pm 5,61$ & & \\
\hline & \multirow{2}{*}{ 4. sinif } & Kadın & 83 & $57,34 \pm 6,04$ & \multirow{2}{*}{2,576} & \multirow{2}{*}{011} \\
\hline & & Erkek & 20 & $53,50 \pm 5,71$ & & \\
\hline \multirow{4}{*}{$\begin{array}{l}\text { İhmalin çocuk üzerin- } \\
\text { deki belirtilerini ta- } \\
\text { nıma }\end{array}$} & \multirow{2}{*}{ 2. sinif } & Kadın & 71 & $28,06 \pm 4,03$ & \multirow{2}{*}{3,656} & \multirow{2}{*}{001} \\
\hline & & Erkek & 43 & $25,33 \pm 3,58$ & & \\
\hline & \multirow{2}{*}{ 4. sinif } & Kadın & 83 & $27,94 \pm 4,55$ & \multirow{2}{*}{1,200} & \multirow{2}{*}{ 233 } \\
\hline & & Erkek & 20 & $26,60 \pm 4,19$ & & \\
\hline \multirow{4}{*}{$\begin{array}{l}\text { İstismar ve ihmale yat- } \\
\text { kın ebeveyn özellikle- } \\
\text { rini tanıma }\end{array}$} & \multirow{2}{*}{ 2. sinif } & Kadın & 71 & $41,62 \pm 5,26$ & \multirow{2}{*}{3,568} & \multirow{2}{*}{001} \\
\hline & & Erkek & 43 & $38,07 \pm 4,95$ & & \\
\hline & \multirow{2}{*}{ 4. sinif } & Kadın & 83 & $42,18 \pm 5,45$ & \multirow{2}{*}{2,192} & \multirow{2}{*}{,034 } \\
\hline & & Erkek & 20 & $40,00 \pm 3,55$ & & \\
\hline \multirow{4}{*}{$\begin{array}{l}\text { İstismar ve ihmale yat- } \\
\text { kın çocuğun özellikle- } \\
\text { rini bilme }\end{array}$} & \multirow{2}{*}{ 2. sinif } & Kadın & 71 & $19,20 \pm 3,57$ & \multirow{2}{*}{1,250} & \\
\hline & & Erkek & 43 & $18,42 \pm 2,55$ & & 214 \\
\hline & $4 \sin f$ & Kadın & 83 & $19,96 \pm 3,39$ & 2800 & 008 \\
\hline & 4. sinif & Erkek & 20 & $18,25 \pm 2,17$ & 2,800 & \\
\hline & 2. sinif & Kadın & 71 & $28,41 \pm 3,88$ & 3.334 & 001 \\
\hline Çocuk istismarı ve ih- & 2. sinit & Erkek & 43 & $25,88 \pm 3,99$ & 3,334 & ,001 \\
\hline $\begin{array}{l}\text { malinde anlesel ozellik- } \\
\text { leri bilme }\end{array}$ & 4. sinif & Kadın & 83 & $29,52 \pm 4,76$ & 1485 & 141 \\
\hline & 4. Sinif & Erkek & 20 & $27,75 \pm 4,88$ & 1,485 & , 141 \\
\hline & $2 \sin 4 f$ & Kadın & 71 & $247,24 \pm 20,41$ & 5113 & 001 \\
\hline Tonlam Ölcek Puranı & 2. sinit & Erkek & 43 & $227,74 \pm 18,56$ & 5,113 & ,001 \\
\hline & & Kadın & 83 & $250,95 \pm 24,19$ & & 001 \\
\hline & 4. Sinif & Erkek & 20 & $234,90 \pm 16,90$ & $3,4 / 5$ & ,001 \\
\hline
\end{tabular}

Öğrencilerin öğrenim gördükleri sınıf ile "Çocuk istismarına ilişkin çocuktaki davranışsal belirtileri bilme" ( $\mathrm{p}=0,022)$, "İstismar ve ihmale yatkın ebeveyn özelliklerini tanıma" ( $\mathrm{p}=0,042)$, “Çocuk istismarı ve ihmalinde ailesel özellikleri bilme" $(\mathrm{p}=0,005)$ ve toplam ölçek puan ortalamaları $(\mathrm{p}=0,022)$ arasında istatistiksel olarak anlamlı bir farklılık saptanmıştır. 4 . sinıfta olan öğrencilerin ölçek ve alt ölçek puan ortalamaları 2. sınıftaki öğrencilerin puan ortalamalarından daha yüksektir. Buna göre 4. sinıfta 
olan öğrencilerin çocuk istismarı ve ihmalinin belirtilerini 2. sınıftaki öğrencilerden daha iyi tanıyabilmektedir (Tablo 3).

Tablo 3. Sınıfa göre ölçek alt ölçek puan ortalamalarının karşılaștırılması

\begin{tabular}{|c|c|c|c|c|c|}
\hline Alt Ölçekler & Sinıf & $\mathbf{N}$ & $\overline{\mathrm{X}} \pm \mathrm{ss}$ & $\mathbf{t}$ & $\mathbf{p}$ \\
\hline \multirow{2}{*}{$\begin{array}{l}\text { İstismarın çocuk üzerindeki } \\
\text { fiziksel belirtilerini tanıma }\end{array}$} & 2. sinif & 114 & $71,49 \pm 7,74$ & \multirow{2}{*}{$-1,442$} & \multirow{2}{*}{ 151 } \\
\hline & 4. sinif & 103 & $73,00 \pm 7,65$ & & \\
\hline \multirow{2}{*}{$\begin{array}{l}\text { Çocuk istismarına ilişkin ço- } \\
\text { cuktaki davranışsal belirti- } \\
\text { leri bilme }\end{array}$} & 2. sinif & 114 & $54,73 \pm 5,78$ & \multirow[b]{2}{*}{$-2,303$} & \multirow[b]{2}{*}{,022 } \\
\hline & 4. sinif & 103 & $56,59 \pm 6,14$ & & \\
\hline \multirow{2}{*}{$\begin{array}{l}\text { İhmalin çocuk üzerindeki be- } \\
\text { lirtilerini tanıma }\end{array}$} & 2. sinif & 114 & $27,03 \pm 4,07$ & \multirow{2}{*}{$-1,124$} & \multirow{2}{*}{,262 } \\
\hline & 4. sinif & 103 & $27,68 \pm 4,49$ & & \\
\hline \multirow{2}{*}{$\begin{array}{l}\text { İstismar ve ihmale yatkın } \\
\text { ebeveyn özelliklerini tanıma }\end{array}$} & 2. sinif & 114 & $40,28 \pm 5,41$ & \multirow{2}{*}{$-2,046$} & \multirow{2}{*}{,042 } \\
\hline & 4. sinif & 103 & $41,76 \pm 5,20$ & & \\
\hline \multirow{2}{*}{$\begin{array}{l}\text { İstismar ve ihmale yatkın ço- } \\
\text { cuğun özelliklerini bilme }\end{array}$} & 2. sinif & 114 & $18,90 \pm 3,23$ & \multirow{2}{*}{$-1,651$} & \multirow{2}{*}{100} \\
\hline & 4. sinif & 103 & $19,63 \pm 3,25$ & & \\
\hline \multirow{2}{*}{$\begin{array}{l}\text { Çocuk istismarı ve ihma- } \\
\text { linde ailesel özellikleri bilme }\end{array}$} & 2. sinif & 114 & $27,46 \pm 4,09$ & \multirow{2}{*}{$-2,821$} & \multirow{2}{*}{,005 } \\
\hline & 4. sinif & 103 & $29,17 \pm 4,81$ & & \\
\hline \multirow{2}{*}{ Toplam Ölçek Puanı } & 2. sinif & 114 & $239,89 \pm 21,82$ & \multirow{2}{*}{$-2,569$} & \multirow{2}{*}{,011 } \\
\hline & 4. sinif & 103 & $247,84 \pm 23,76$ & & \\
\hline
\end{tabular}

Tablo 4'te "Çocuk istismarı ve ihmalinin tanımlanması ölçeği" alt ölçek puan ortalamalarının değerlendirmesinde en yüksek puanın "İhmalin çocuk üzerindeki belirtilerini tanıma" $(3,91 \pm 0,61)$, en düşük puanın ise "İstismar ve ihmale yatkın çocuğun özelliklerini bilme" $(3,21 \pm 0,54)$ alt ölçeğinde olduğu belirlenmiştir.

Tablo 4. Çocuk istismarı ve ihmalinin tanılanması ölçeği alt ölçek madde puan ortalamaları

\begin{tabular}{llll}
\hline Alt Ölçekler & $\mathbf{N}$ & $\overline{\mathrm{X}}$ & ss. \\
\hline İstismarın çocuk üzerindeki fiziksel belirtilerini tanıma & 217 & 3,80 & 0,41 \\
Çocuk istismarına ilişkin çocuktaki davranışsal belirtileri & 217 & 3,71 & 0,40 \\
bilme & 217 & 3,91 & 0,61 \\
İhmalin çocuk üzerindeki belirtilerini tanıma & 217 & 3,42 & 0,45 \\
İstismar ve ihmale yatkın ebeveyn özelliklerini tanıma & 217 & 3,21 & 0,54 \\
İstismar ve ihmale yatkın çocuğun özelliklerini bilme & 217 & 3,53 & 0,56 \\
Çocuk istismarı ve ihmalinde ailesel özellikleri bilme & &
\end{tabular}

\section{Tartışma}

Çalışmada, hemşirelik öğrencilerinin Çİ̈BRTÖ bilgi puanlarının genel or-

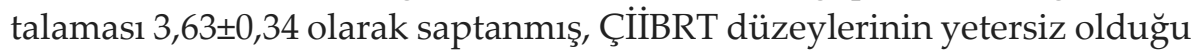


görülmüştür. Literatürde konu ile ilgili çalışmaların daha çok mezun hemşirelerle yapıldığı ve benzer bulgulara ulaşıldığı (Burç ve Güdücü Tüfekçi, 2015; Külcü Polat ve Karalaş, 2016; Metinyurt ve Sarı, 2016), hemşirelik öğrencileriyle yapılan sınırlı sayıda ki çalışmalarda aynı şekilde öğrencilerin Çi̇̇ ile ilgili bilgilerinin yetersiz ve eğitim gereksinimleri olduğu bildirilmiştir (Akgün Kostak ve Vatansever, 2015; Poreddi ve ark., 2016).

Çalışmada kadın olan, Çi̇̇ ile ilgili eğitim almış olan, Çi̇̇ eğitimini okul aracılı̆̆ ile almış olan ve Çi̇̇ konusunda eğitim almak isteyen öğrencilerin Çİ̈BRT düzeylerinin daha yüksek olduğu ve gruplar arasında farkın önemli olduğu saptanmıştır. Literatürde bulgularımıza paralel olarak kadın olma, mezuniyet öncesi Çi̇̇ konusunda eğitim alma durumunun ÇİİBRT düzeyini artırdığı dikkati çekmektedir (Akgün Kostak ve Vatansever, 2015; Burç ve Güdücü Tüfekçi, 2015; Pakiş ve ark., 2015). Benzer şekilde bir çalışmada kadın cinsiyetinin şiddete en çok uğrayan taraf olması nedeniyle çocuğa yönelik şiddete duyarlılıklarının da daha yüksek olduğu bildirilmiştir (Özyürek, 2017). Bulgularımıza benzer şekilde yurt d1şında yapılan bir çalışmada hemşirelik öğrencilerine Çi̇̇ konusunda verilen eğitimlerin bilgi ve tutumlarını artırdığı belirtilmektedir (Elarousy, Helal ve Villiers, 2012).

Çalışmada öğrencilerin \%67,7'si Çi̇̇ konusunda eğitim aldıklarını, \%19,8'i ise Çi̇̇ eğitimini okulda öğrenimleri sırasında aldıklarını belirtmiştir. Yapılan çalışmalarda ülkemizde sağlık bilimleri fakültesi öğrencilerinin \%40,8'1 (Akgün Kostak ve Vatansever, 2015), yurt dışında ise diş hekimliği fakültesi öğrencilerinin \%9'u (Hashim ve Al-Ani, 2013) Çi̇̇ hakkında bilgi aldıklarını bildirmiştir. Literatür incelendiğinde bulgularımıza paralel olarak sağlık personelinin mesleki öğrenimleri sırasında çi̇̇ konusunda eğitim alma oranının yetersiz olduğu vurgulanmaktadır (Burç ve Güdücü Tüfekçi, 2015; Külcü Polat ve Karalaş, 2016; Metinyurt ve Sarı, 2016).

Çalışmada öğrencilerin \%18'i Çiì konusunda eğitime gereksinim duymadıklarını ifade etmesine rağmen Çİ̈BRT düzeyleri daha düşük bulunmuştur. Oysa ki ÇİI'nin erken tanılanabilmesi, yasal bildirimlerinin yapılabilmesi ve önlemlerin alınabilmesi için hemşirelerin eğitimleri sırasında bilgilenmeleri, olumlu bir tutum geliştirmeleri son derece önemlidir (Fraser ve ark., 2010). Çalışma bulgusuna göre Çiİ konusunda eğitim almak isteyen öğrencilerin (\%82) istismar ve ihmal konusunda hassasiyetlerinin 
ve farkındalıklarının daha yüksek olduğu, eğitime gereksinim duymayanların ise yetersizliklerinin farkında olmadığı düşünülmektedir. Benzer şekilde Poreddi ve arkadaşları da (2016) çoğu hemşirelik öğrencinin Çi̇̇ şüphesi olan vakaları tanılayıp raporlandırmada kendine güvendiğini, ancak bu konularda bilgilerinin yetersiz olduğunu saptadıklarını belirtmiştir. Hemşirelerin ÇİI konusunda bilgi ve tutumlarını içeren çalışmalarda katılımcların büyük bir kısmı Çi̇̇ konusunda daha fazla eğitim almak istediğini belirtmişlerdir (Gölge, Hamzaoglu ve Türk, 2012; Külcü Polat ve Karalaş, 2016). Ancak bu çalışmalarda, eğitime gereksinim duyan ve duymayan katılımcıların Çiİ ile ilgili bilgi puanlarının etkileşimine bakılmamiştır.

Çalışmada öğrencilerin kardeş sayısı arttıkça Çï̈BRT düzeylerinin azaldığ1 ve ailesi şehirde yaşayan öğrencilerin Çİ̈BRT düzeylerinin anlamlı derecede daha yüksek olduğu saptanmıştır. Literatür incelediğinde sağlık personelinin ya da adaylarının Çİ̈BRT düzeylerini değerlendiren çalışmalarda bu değişkenlerin ele alınmadığı, bir çalışmada ise hemşirelerin sahip oldukları çocuk sayısı arttıkça Çï̈BRT düzeylerinin azaldığı görülmüştür (Yılmaz, 2015). Ancak ailede çocuk sayısının ikiden fazla olmasının Çiï için önemli bir risk faktörü olduğu (Geçkil, 2017), kırsal bölgede yaşayan ailelerde daha fazla Çi̇̇ yaşandığı (Akçınar, 2017) belirtilmektedir.

Çalışmada öğrencilerin \%75,6'sı Çiİ konusunda yasal sorumluluklarını bilmediklerini belirtmiş ve bu öğrencilerin ÇİiBRT düzeylerinin daha düşük olduğu saptanmış ancak bu farkın önemli olmadığı görülmüştür. ÇİI'nin önlenmesinde önemli sorun karşılaşılan olguların bildirilmemesidir. Bu konuyla ilgili yapılan çalışmalarda sağlık çalışanlarının Çiỉ konudaki yasal sorumluluklarını yeterince bilmedikleri (Yağmur ve Balcı, 2009), olguların raporlandırılmasında bilgisizlik nedeniyle bildirim yapmadıklarını belirtilmektedir (Burç ve Güdücü Tüfekçi, 2015; Gölge, Hamzaoglu ve Türk, 2012).

Literatürde ebeveynlerin eğitim düzeyinin ve ailenin gelir düzeyinin düşük olmasının, ailenin geniş aile yapısında olmasının Çi̇̇ riskini artırdığı bildirilmektedir (Kurt ve ark., 2017; Sinan, Tosun ve Ünal, 2017). Çalışmada anne ve baba eğitimi ortaokul ve üzerinde olan, ailesinin ekonomik geliri giderinden daha fazla olan, çekirdek aileye sahip olan, çocuk sahibi olan öğrencilerin Çi̇iBRT düzeylerinin daha yüksek olduğu, fakat 
gruplar arasındaki farkın önemsiz olduğu saptanmıştır. Koçak ve Büyükgönenç (2011) ise bulgularımıza benzer şekilde okur yazar olmayan ve ilköğretim mezunu olan erişkinlerin Çi̇̇ konusunda bilgilerinin yetersiz olduğunu belirtmiş ancak bulgularımızdan farklı olarak gelir düzeyi düşük ailelerin Çiİ'de etkisi olan faktörleri daha fazla bildiklerini ve henüz çocuk sahibi olmayanların Çi̇i konusunda daha çok bilgisi olduğunu ifade etmiştir.

Çalışmamızda Çiì olgusu ile karşılaşan, Çiì'yi tanımada yeterli olduğunu düşünen, Çiİ olgusuna nasıl yaklaşımda bulunacağını bildiğini düşünen, Çiİ ile ilgili yasal sorumluluklarını bildiğini düşünen öğrencilerin Çİ̈BRT düzeylerinin daha yüksek olduğu, fakat gruplar arasındaki farkın önemsiz olduğu saptanmıştır. Konu ile ilgili yapılan çalışmalar incelendiğinde bulgularımıza benzer şekilde hemşire, ebe ve diğer sağlık personelinin Çi̇̇ olgusu veya şüphesi ile karşılaşma durumlarının Çi̇̈BRT düzeylerini etkilemediği (Burç ve Güdücü Tüfekçi, 2015; Çatık ve Çam, 2006; Metinyurt ve Sarı, 2016), hekimlerle yapılan bir çalışmada ise Çİ̈BRT düzeylerini etkilediği bulunmuştur (Kara, Çalışkan ve Suskan, 2014). Çalışmamızda sağlık meslek lisesinden mezun olan öğrencilerin ÇïBRT düzeylerinin daha yüksek olduğu ancak bu farkın önemli olmadığı saptanmıştır. Bu sonuç bize sağlık meslek lisesi mezunu öğrencilerinin diğer gruplara göre, sağlık hizmetleri sektörü içerisinde daha uzun süre yer almasının Çi̇̇ konusunda farkındalıklarının artmasına katkı sağladığını düşündürmektedir. Konu ile ilgili yapılan çalışmalarda hemşirelerin öğrenim düzeyi arttıkça, Çİ̈BRT düzeylerinin de arttığı bildiren çalışmaların (Burç ve Güdücü Tüfekçi, 2015) yanı sıra, mezun olunan okulun Çİ̈BRT düzeyini etkilemediğini belirten çalışmaların olduğu (Çatık ve Çam, 2006) görülmektedir.

4. sınıf öğrencilerinin Çİ̈BRT düzeyleri 2. sınıflara göre daha yüksek bulunmuştur. Dördüncü sınıf öğrencilerinin "Çocuk istismarına ilişkin çocuktaki davranışsal belirtileri bilme", "İstismar ve ihmale yatkın ebeveyn özelliklerini tanıma", "Çocuk istismarı ve ihmalinde ailesel özellikleri bilme" alt boyut puan ortalamaları ve Çİ̈BRTÖ toplam puan ortalamalarının daha yüksek olduğu ve puan ortalamaları arasındaki farkın istatistiksel olarak anlamlı olduğu görülmüştür. Çalışma bulgularımıza benzer şekilde Poreddi ve arkadaşları (2016) dördüncü sınıf hemşirelik öğrencilerinin ikinci sınıflara göre, Elarousy ve arkadaşları (2012), 25 yaş 
üzeri hemşirelik öğrencilerinin 25 yaş altına göre Çi̇̇ konusunda daha iyi bilgi ve tutum gösterdiğini, Akgün Kostak ve Vatansever (2015)' de sağlık bilimleri fakültesi 4 . sınıf öğrencilerinin alt sınıf öğrencilerine göre Çi̇i konusunda daha fazla bilgi aldıklarını bildirmiştir. Bu bulgular son sınıf öğrencilerinin birinci sınıftan son sınıfa kadar mesleki eğitimlerinin teorik ve uygulama süreçlerinde Çii் konusu ile ilgili kazanımlarının arttığını göstermektedir. Ayrıca hemşirelik eğitim müfredatının 3. ve 4. yıllarında ÇIï konusunun daha iyi kavranmasına hizmet eden, pediatri, ruh sağlığı, halk sağlı̆̆ ve acil bakım gibi teorik ve uygulamalı derslerin bulunmasının öğrencilerin Çİ̈BRT düzeylerinin artmasını sağladığı düşünülebilir.

\section{Sonuç}

Bu çalışmada hemşirelik öğrencilerinin Çİ̈BRT düzeylerinin istendik düzeyde olmadığı, Çİ̈ konusunda yasal sorumluluklarını bilmedikleri ve eğitime gereksinim duydukları belirlenmiştir. Çi̇i konusunda eğitim almiş olan ya da eğitim almaya istekli olan, bu eğitimi öğrenimleri sürecinde alan, kadın olan, ailesi şehirde yaşayan öğrencilerin Çi̇̈BRT düzeylerinin daha yüksek olduğu saptanmıştır. Öğrencilerin kardeş sayısı arttıkça ÇİİBRT düzeylerinin düştüğü görülmüştür. Ayrıca 4. sınıf öğrencilerinin 2. sinıflara göre Çİ̈BRT düzeyleri daha yüksek bulunmuştur. Öğrencilerin en fazla ihmalin çocuk üzerindeki belirtilerini tanıdığı, en az ise istismar ve ihmale yatkın çocuğun özelliklerini tanıdı̆̆ı belirlenmiştir. Çalışmadan elde edilen bulgulara göre öğrencilerin Çiİ'ye karşı mesleki sorumluluk ve rollerini kazanabilmeleri için hemşirelik müfredatında çi̇̈ konusuna daha çok yer verilmesi, kapsamının tüm sınıfları içine alacak şekilde düzenlenmesi ve özellikle erkek öğrenciler başta olmak üzere, öğrencilerin bilgi düzeyleri gözden geçirilerek mezuniyet öncesi gerekli tekrarların yapılması önerilebilir. Ayrıca çalışma bulgularımızdan hareketle hemşirelik öğrencilerinin kardeş sayısı ve ailenin yaşadığı yer gibi ailesel ve kültürel özellikleri, çocukluk döneminde istismara maruz kalma durumları ve ÇİİBRT düzeylerinin etkileşimlerini değerlendiren çalışmanın planlaması, kültürel özelliklerinin getirdiği yanlış ve eksik bilgilerin değiştirilmeye çalışılması önerilebilir. 


\title{
EXTENDED ABSTRACT
}

\section{Nursing Students' Level of the Diagnosing Symptoms and Risks of Child Abuse and Neglect}

\author{
Emine Güdek Seferoğlu - Emel Sezici - Deniz Yiğit \\ Kütahya Health Sciences University - Eskişehir Osmangazi University
}

Neglect and abuse in childhood affects children's physical, mental or social development and it causes many problems ranging from adulthood. Therefore, the protection of children's physical and mental health is very important. The healthcare workers have critical role in early diagnosis, following the necessary procedures, prevention of child abuse and neglect in which threatens public health with the impact on the child health and the long-term consequences. However, we observe insufficient practices in identifying or recording child abuse and neglect cases in our country.

This study has aimed to determine the capability level of the future health staff, the nursing students, in recognizing the signs and risks of child abuse and neglect.

The study has been conducted on the students who have been studying in the 2nd and 4th year of nursing faculty of a university, during the spring semester in 2017-2018 Academic Year. The samples cover 217 students $(92 \%)$ who met the study criteria. The data were obtained by using "The Identification Information Form" and "Scale of Diagnosing Symptoms and Risks of Child Abuse and Neglect" and collected under the control of the researchers. The students who participated the study were outside the class hours. The statistical analysis of the data was performed using 20.0 SPSS package program, applying the frequency, percentages, the Student's t-test and one-way analysis of variance methods.

It has been found that $71 \%$ of the students are female, $56.1 \%$ of the student's mothers and $41.5 \%$ of student's fathers have primary or lower education level, $76.5 \%$ of student's family have tight household income, $84.3 \%$ of the families are in core family structure, $59 \%$ have 2 siblings, and $75.6 \%$ of the families live in the cities. The $67.7 \%$ of the students have received 
information about child neglect and abuse, $19.8 \%$ have claimed they received the information at the school, $80.2 \%$ have not heard about child neglect and abuse concept, $43.8 \%$ considers themselves self-sufficient in defining child abuse and neglect, $75.6 \%$ have not been aware of their legal responsibilities related to child neglect and abuse, and $82 \%$ wanted to receive training on this subject. The overall average of the students' scores of the Diagnosing of Symptoms and Risks of Child Abuse and Neglect Scale was $243.65 \pm 23.05$. In the survey, the students, who are 4 th graders, female, have been trained on Child abuse and neglect subject, have received this education through schools, have families living in cites and have wanted to study in child abuse and neglect, have summed higher Child Abuse and Neglect Symptoms and Risk Assessment Scale score $(p<0.05)$. It has been observed that competency level in the recognizing of the symptoms and risks of child abuse and neglect decreases with the higher number of student's siblings, and the difference between the groups was significant $(\mathrm{p}<0.05)$. Additionally, it has been observed that the identification of symptoms and risk levels of child abuse and neglect were decreased in students when the number of siblings increases ( $p$ $<0.05)$.

It has been determined that the nursing students' ability to recognize the symptoms and risks of child abuse and neglect is not at an expected level, they are not aware of their legal responsibilities about child abuse and neglect and need education. It has been determined that the students were mostly recognized the symptoms of the neglect on the child, and less recognized the characteristics of the child who is susceptible to abuse and neglect. According to our findings child abuse and neglect should be given more place in nursing education to gain professional responsibility to students and to include all classes, especially male students. In addition, the level of knowledge of child abuse and neglect should be reviewed before graduation. 


\section{Kaynakça / References}

Akçınar, B. (2017). Aile sistemlerinde şiddetin döngüsü. Itobiad: Journal of the Human \& Social Science Researches, 6(4), 40-64.

Akgün Kostak, M. ve Vatansever, C. (2015). Sağllk bilimleri fakültesi öğrencilerinin çocuk istismarı ve ihmali ile ilgili görüş ve düşünceleri. Sağllk Bilimleri ve Meslekleri Dergisi, 2(1), 1-11. http://dx.doi.org/10.17681/hsp.79915.

Bakır, E. ve Kapucu, S. (2017). Çocuk ihmali ve istismarının Türkiye'de yapılan araştırmalara yansıması: Bir literatür incelemesi. Journal of Hacettepe University Faculty of Nursing, 4(2), 13-24.

Ben, Y. Y., Attar-Schwartz, S., Ziv, A., Jedwab, M. ve Benbenishty, R. (2010). Child abuse and neglect: Reporting by health professionals and their need for training. The Israel Medical Association journal: IMAJ, 12(10), 598-602.

Burç, A. ve Güdücü Tüfekçi, F. (2015). Hemşirelerin çocuk istismarı ve ihmalinin belirti ve risklerini tanılama düzeyleri. Acıbadem Universitesi Saghk Bilimleri Dergisi, 6(3), 144-151.

Caneira, L. ve Myrick, K. M. (2015). Diagnosing child abuse: The role of the nurse practitioner. The Journal for Nurse Practitioners, 11(6), 640646. http://dx.doi.org/10.1016/j.nurpra.2015.03.017

Ceccucci, J. (2018). Evaluating nurse practitioners perceived knowledge, competence, and comfort level in caring for the sexually abused child. Journal of Forensic Nursing, 14(1), 42-49. http://dx.doi.org/10.1097/JFN.0000000000000184

Çatık, A. E. ve Çam, O. (2006). Hemşire ve ebelerin çocuk istismarı ve ihmalinin belirti ve risklerini tanıma düzeylerinin saptanması. Ege Üniversitesi Hemşirelik Yüksek Okulu Dergisi, 22(2), 103-119.

Elarousy, W., Helal, H. ve Villiers L. (2012). Child abuse and neglect: Student nurses' knowledge and attitudes. Journal of American Science, 8(7), 665-674. http://dx.doi.org/10.1037/e516542013-061

Engh Kraft, L., Rahm, G. ve Eriksson, U. B. (2017). School nurses avoid addressing child sexual abuse. The Journal of School Nursing, 33(2), 133-142. http://dx.doi.org/10.1177\%2F1059840516633729 
Fraser, J. A., Mathews, B., Walsh, K., Chen, L. ve Dunne, M. (2010). Factors influencing child abuse and neglect recognition and reporting by nurses: A multivariate analysis. International Journal of Nursing Studies, 47(2), 146-153. http://dx.doi.org/10.1016/j.ijnurstu.2009.05.015

Geçkil, E. (2017). Çocuklarda fiziksel istismar ve hemşirelik yaklaşımı. Gümüşhane Üniversitesi Sağllk Bilimleri Dergisi, 6(1), 129-139.

Gölge, Z.B., Hamzaoglu, N. ve Türk, B. (2012). Sağlık çalışanlarının çocuk istismarı ve ihmali konusundaki farkındalık düzeylerinin ölçülmesi. Adli Ttp Dergisi, 26(2), 86-96. https://dx.doi.org/10.5505/adlitip.2012.36349

Güner, C. K., Yavuz, H. Ö. ve Dörtbudak, Z. (2016). Çocuk istismarı-ihmali vakalarıyla karşılaşan hemşirelerin görüş ve uygulamaları. Să̆glk Akademisi Kastamonu, 1(1), 39-55. http://dx.doi.org/10.25279/sak.204994

Hashim, R. ve Al-Ani, A. (2013). Child physical abuse: assessment of dental students' attitudes and knowledge in United Arab Emirates. European Archives of Paediatric Dentistry, 14(5), 301-305. http://dx.doi.org/10.1007/s40368-013-0063-2

Kara, Ö., Çalışkan, D. ve Suskan, E. (2014). Ankara ilinde görev yapan çocuk asistanları, uzmanları ve pratisyen doktorların çocuk istismarı ve ihmali konusunda bilgi düzeyleri ve yaklaşımlarının karşılaştırılması. Türk Pediatri Arşivi, 49, 57-65. http://dx.doi.org/10.5152/tpa.2014.984

Karakuş, Ö. (2012). Relation between childhood abuse and self esteem in adolescence. International Journal of Human Sciences, 9(2), 753-763.

Koçak, C. ve Büyükgönenç, L. (2011). Toplumdaki bireylerin çocuk istismarı ve ihmaline yönelik bilgi ve görüşleri. Hitit Üniversitesi Sosyal Bilimler Enstitüsü Dergisi, 4(1), 89-104.

Kurt, G., Dönmez, S., Eren, Ö., Balcı, E. ve Günay, O. (2017). Üç farklı disiplinde okuyan üniversite son sinıf öğrencilerinin istismar, ihmal ve aile içi şiddet algıları. Journal of International Social Research, 10(50), 405-414.

Külcü Polat, D. ve Karalaş, H. (2016). Çocuk kliniklerinde çalışan hemşirelerin çocuk istismarı ve ihmali konusunda bilgi düzeylerinin incelenmesi. Ege Üniversitesi Hemşirelik Fakültesi Dergisi, 32(1), 48-58. 
Kürklü, A. (2011). Öğretmenlerin çocuk istismarı ve ihmaline yönelik farkındalık düzeyleri. Yüksek Lisans Tezi, Afyon Kocatepe Üniversitesi Sağlık Bilimleri Enstitüsü, Afyon.

Lee, H. M. ve Kim, J. S. (2018). Predictors of intention of reporting child abuse among emergency nurses. Journal of Pediatric Nursing, 38, e47-e52. http://dx.doi.org/10.1016/j.pedn.2017.10.007

Metinyurt, H. A. I. ve Sarı, H. Y. (2016). Sağlık çalışanlarının çocuk ihmali ve istismarını tanıma düzeyleri. Çocuk ve Medeniyet Dergisi, 1(1), 101-121.

Özgentürk, İ. (2014). Çocuk istismarı ve ihmal. International Journal of Human Sciences, 11(2), 265-278.

Özyürek, A. (2017). Çocuğa yönelik şiddete duyarlık ölçeği geliştirme çalışması. Karabük Üniversitesi Sosyal Bilimler Enstitüsü Dergisi, 7(2), 462-472.

Pakiş, I., Demir, F., Bektas, G., Altun, U. ve Yıldırım, S. (2015). Investigation of the awareness and knowledge about child abuse and negligence among doctors and nurses working in the east part of Turkey. Romanian Journal of Legal Medicine, 23(2), 151-156. http://dx.doi.org/10.4323/rjlm.2015.151

Poreddi, V., Pashapu, D. R., BV, K., Gandhi, S., El-Arousy, W. ve Math, S. B. (2016). Nursing students' knowledge of child abuse and neglect in India. British Journal of Nursing, 25(5), 264-268. http://dx.doi.org/10.12968/bjon.2016.25.5.264

Sinan, Ö., Tosun, B. ve Ünal, N. (2017). Hemşirelik öğrencilerinin şiddete bakışı. Türkiye Klinikleri Journal of Psychiatric Nursing-Special Topics, 3(2), 108-114.

Sekhar, D. L., Kraschnewski, J. L., Stuckey, H. L., Witt, P. D., Francis, E. B., Moore, G. A., Morgan P. L. ve Noll, J. G. (2018). Opportunities and challenges in screening for childhood sexual abuse. Child Abuse ENneglect, $\quad 85, \quad$ 156-163. http://dx.doi.org/10.1016/j.chiabu.2017.07.019

Türker, G. (2017). Aile hekimleri, hemşire ve ebelerin çocuk istismarı ve ihmali konusunda farkındalık düzeyleri: Burdur örneği. Yüksek Lisans Tezi, Selçuk Üniversitesi Sağlık Bilimleri Enstitüsü, Konya. 
Uysal, A. (1998). Çocuk İstismarı ve İhmalinin Belirti ve Risklerini Tanılamada Hemşire ve Ebelerin Bilgi Düzeylerinin Saptanması. Yüksek Lisans Tezi, Ege Üniversitesi Sağlık Bilimleri Enstitüsü, İzmir.

World Health Organization. Child Maltreatment. http://www.who.int/mediacentre/factsheets/fs150/en/. Erişim Tarihi: 26.07.2018.

Yağmur, F. ve Balcı, E. (2009). Kayseri ili merkez ve ilçeleri birinci basamak sağlık çalışanlarının, çocuk istismarı ve ihmali konusunda bilgi düzeyleri: Anket çalışması. Adli Bilimler Dergisi, 8, 7-11.

Yılmaz, B. (2015). Bir hastanede çalışan hemşirelerin çocuk ihmal ve istismarına yönelik bilgi ve yaklaşımlarının incelenmesi. Yayınlanmamış Yüksek Lisans Tezi. Ankara Üniversitesi.

\section{Kaynakça Bilgisi / Citation Information}

Güdek-Seferoğlu, E., Sezici, E. ve Yiğit, D. (2019). Hemşirelik öğrencilerinin çocuk istismarı ve ihmalinin belirti ve risklerini tanılama düzeyleri. OPUS-Uluslararası Toplum Araştırmaları Dergisi , 10(17), 257-276. DOI: 10.26466/opus.511405 